\title{
Deaths Exceeded Births in Nearly Half of U.S. Counties Last Year
}

Kenneth M. Johnson

$\mathrm{E}$ ven before the onset of the SARS-CoV-2 pandemic, deaths were at a record high in the United States last year $(2,835,000)$, but there were the fewest births $(3,792,000)$ since 1986 , according to new Census Bureau estimates. Between July 2018 and July 2019, the surplus of births over deaths $(957,000)$ was the least in more than 50 years. Because of this smaller surplus and diminished immigration, the U.S. population grew by just 0.48 percent last year-the lowest population growth rate since 1919. With more deaths and fewer births, more people died than were born last year in 1,430 of the 3,142 U.S. counties (46 percent). The extent of this natural decrease (when deaths exceed births) is increasing. Ten years ago, just 889 counties (28 percent) had more deaths than births. Once natural decrease occurs, it is likely to reoccur. Between 2010 and 2019, 20 percent of counties had natural decrease every year, 19 percent in 1 to 4 years, and 23 percent in 5 to 8 years. Only 39 percent of all counties had more births than deaths in every year.

Natural decrease occurs more in rural than urban areas. It is widespread in agriculture, mining, timber processing, and older industrial regions. Natural decrease is more common in counties with larger proportions of older adults, fewer women of child-bearing age, and low fertility rates. Since the Great Recession, fertility has diminished the most among younger women and it is unclear whether these births are being delayed or will be foregone. This has significant implications for the future incidence of natural decrease, as does the rapidly unfolding SARS-CoV-2 pandemic.

\section{NUMBER OF YEARS IN WHICH COUNTY DEATHS EXCEEDED BIRTHS, 2010 TO 2019}

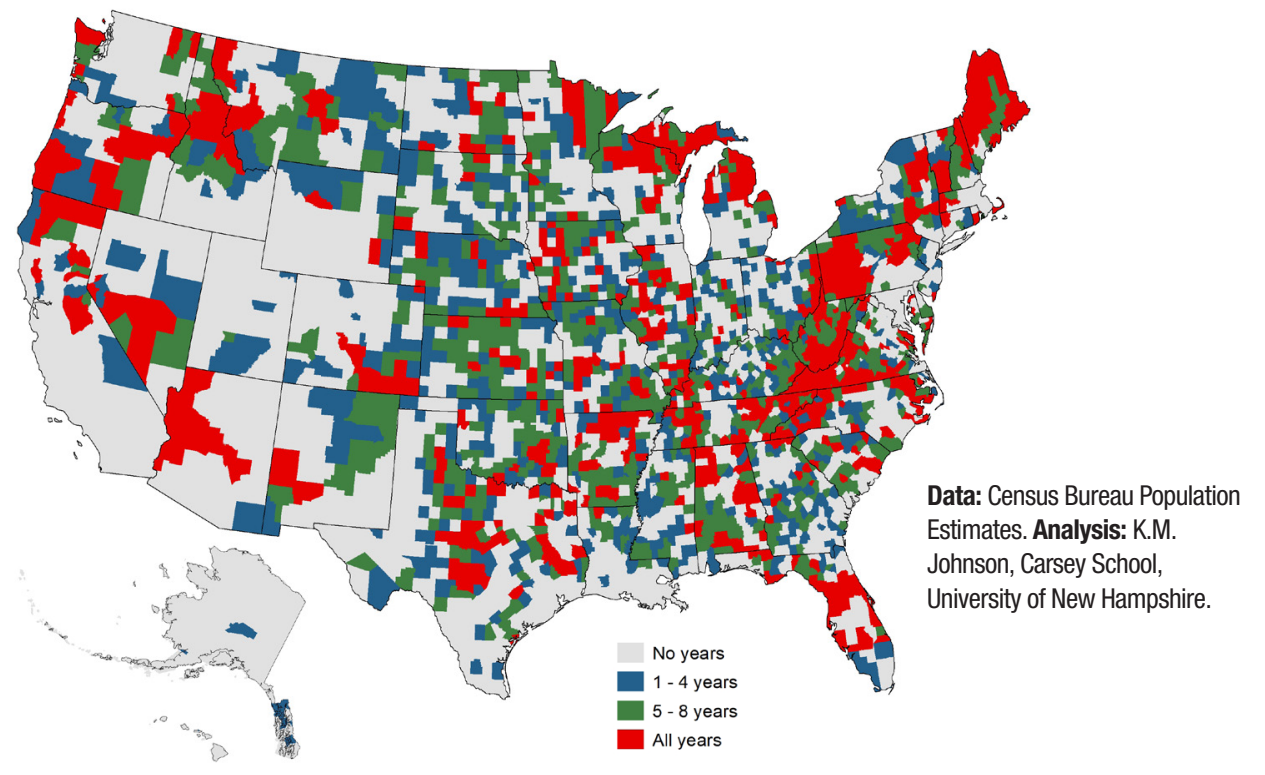

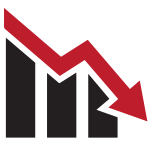

In the United States, fewer births and more deaths reduced population growth to a 100 -year low. In nearly 46 percent of counties, more people died than were born last year.

\section{See Related Publications at carsey.unh.edu \\ - U.S. Fertility Rate Hits Record Low and Births Continue to Diminish (May 2019) \\ - U.S. Population Growth Continues to Slow Due to Fewer Births and More Deaths (December 2018)}

\footnotetext{
About the Author

Kenneth M. Johnson is Senior Demographer at the Carsey School of Public Policy, Professor of Sociology at the University of New Hampshire, and an Andrew Carnegie Fellow.

This research was supported by his Andrew Carnegie Fellowship and the New Hampshire Agricultural Experiment Station in support of Hatch Multi-State Regional Project W-4001 through joint funding of the National Institute of Food and Agriculture, USDA. The content is solely the responsibility of the author and it does not necessarily represent the official views of the sponsoring organizations.
}

Huddleston Hall • 73 Main Street • Durham, NH 03824 carsey.unh.edu $\bullet 603.862 .2821$
TTY USERS: DIAL 7-1-1 OR

1-800-735-2964 (RELAY N.H.) 